\title{
FECAL MICROBIOLOGY IN PUPPIES SUPPLEMENTED WITH PROBIOTICS RECEIVING DIFFERENT DIETS
}

\author{
FELICIANO, Marcus Antonio Rossi ${ }^{1}$ \\ SAAD, Flavia Maria de Oliveira Borges ${ }^{2}$ \\ AQUINO, Adriana Augusto ${ }^{3}$ \\ PICOLLI, Roberta Hilsdorf ${ }^{2}$ \\ SILVA, Marco Augusto Machado ${ }^{4}$ \\ SANTOS, Victor Jose Correia ${ }^{5}$ \\ VICENTE, Wilter Ricardo Russiano ${ }^{4}$
}

\begin{abstract}
SUMMARY: The aim of this research is to evaluate supplementation effects of two probiotics to Beagle puppies receiving two diets (high and low quality) over microbiote and faecal $\mathrm{pH}$. They were used 18 Beagle puppies shared in three treatments : 1) treatment 1: control (food); 2) treatment 2: food with probiotic 1 (Bifidobacterium); 3) treatment 3: food with probiotic 2 (Lactobacillus). Research was shared in two levels, each charactherized to different quality foods changing. It was used food fats how stress agent. Analysis made were water and foods microbiology and faecal microbiology (E. coli, Lactobacillus, Bifidobacterium and Clostridium sp.). It was verified significative results $(\mathrm{P}<0,05)$ in faecal microbiote with probiotics useful. It was verified differences in $\mathrm{pH}$ analysis $(\mathrm{P}<0,05)$ with probiotics useful too. It was concluded that probiotic 1 present more efectivity in gastrintestinal tract (beneffic) for Beagle puppies.
\end{abstract}

Keywords: Microbiology. Probiotics. Canine nutrition.

\section{MICROBIOLOGIA FECAL EM CÃES FILHOTES SUPLEMENTADOS COM PROBIÓTICOS RECEBENDO DIFERENTES DIETAS}

\begin{abstract}
RESUMO: Este trabalho tem como objetivo avaliar os efeitos da suplementação de dois tipos de probióticos para cães filhotes da raça Beagle, recebendo dois tipos de dieta (de alta e baixa qualidade) sobre a microbiota e o pH fecais. Foram utilizados 18 cães filhotes da raça Beagle, dividido em três tratamentos: 1) tratamento 1: controle (ração); 2) tratamento 2: ração com probiótico 1 (Bifidobacterium); tratamento 3: ração com probiótico 2 (Lactobacillus). $\mathrm{O}$ experimento foi dividido em duas fases, sendo cada uma, caracterizada pela mudança da dieta de qualidades diferentes. Foi utilizado o jejum alimentar como agente estressante. As análises realizadas foram microbiologia da água e das dietas fornecidas e microbiologia fecal (E. coli, Lactobacillus, Bifidobacterium e Clostridium sp.). Verificaram-se resultados significativos $(\mathrm{P}<0,05)$ na microbiota fecal com a utilização dos probióticos. Também, notou-se diferenças na análise do $\mathrm{pH}(\mathrm{P}<0,05)$ com a utilização de probióticos. Concluiu-se que o probiótico 1 apresenta maior efetividade no trato gastrintestinal (benéfica) para cães filhotes da raça Beagle.
\end{abstract}

Palavras-chave: Microbiologia. Probióticos. Nutrição canina

\section{INTRODUCTION}

The products contain probiotics most commonly lactate producing bactéria such as Lactobacillus and Bifidobacterium (Swanson et al., 2002), bacteria of the genus Baccilus (Coppola e Turnês, 2004) and Enterococcus. Considering the importance of intestinal microbiota and the action of bacteria to

\footnotetext{
${ }^{1}$ Pós-doutorando UNESP - Jaboticabal.

${ }^{2}$ Prof ${ }^{a}$. Dra. UFLA

${ }^{3}$ Pós-doutoranda USP

${ }^{4}$ Dr. UNESP - Jaboticabal

${ }^{5}$ Mestrando UNESP - Jaboticabal
} 
maintain their balance in the intestinal environment, several authors agree that probiotics can be used affected (Fernandez et al., 2000). According to these authors the use of probiotics can be recommended in monogastric in three different situations: 1) assist in maintaining the stability of non-pathogenic intestinal microbiota; 2) restore the stability of intestinal microbiota after an imbalance; and 3) promote the stability of the microbiota intestinal no-pathogenic in newborns.

The objective of this study was to evaluate the effects of supplementation of two types of probiotics for puppies Beagle receiving two types of diet (high and low quality) on the fecal microbiota and $\mathrm{pH}$ considering the importance of functional food for the control and aid in the treatment of gastrointestinal disease of dogs.

\section{MATERIAL E METHODS}

Used 18 puppies Beagle with 2 to 6 months of age randomly assigned to three treatments: 1) control (administration only diet); 2) administration of feed + probiotic 1; and 3) administration of feed + probiotic 2 .

The probiotic 1 contained in formulation its Bifidobacterium 1,0 x $108 \mathrm{UFC} / \mathrm{g}$, Lactobacillus 9,1 x $107 \mathrm{UFC/g}$ e Enterococcus 1,2 x $108 \mathrm{UFC/g}$. the composition of the probiotic 2 was Lactobacillus 4,3 x $108 \mathrm{UFC} / \mathrm{g}$, Enterococcus 3,1 x $108 \mathrm{UFC} / \mathrm{g}$ and Pediococcus 3,5 x $108 \mathrm{UFC} / \mathrm{g}$.

The experiment was divided two phases: 1) evaluate and compare the effects of probiotics with the change of a high quality diet (Super Premium) for a standard commercial diet (Standard), 2) evaluate and compared the effects of probiotics with change of a standard commercial diet to a Super Premium food. The Super Premium and Standard terminologies are commonly used in commercial food industry for dogs and cats and among consumers. These designations are used throughout this paper to describe the diets of higher quality and standard respectively.

\section{FIRST PHASE}

In the first phase the animals underwent 11 days of adaptation to nutritional Super Premium housed in collective pens and respect the division of the treatments proposed. On the twelfth day there was a 24 hours fast. On the thirteenth day the animals began to receive standard diet and began supplementing with probiotics orally.

After 11 days of adaptation of animals to the Super Premium and prior to fasting for 24 hours and change of feed, fecal collection was perfomed in all animals. After fasting the animals began to receive standard diet and supplementation with probiotics (except the control treatment) every 12 hours the dosage recommended by the manufacturer (three grams a day for each dog recommended for animals under stress or inflammatory disease of the gastrointestinal tract). On the last day of administration of probiotics was repeated collection for each treatment. 
The Standard commercial feed was provide for seven days. On the last day supply of feed, feces was collected for microbiology of all animals which served as parameters for phase 2.

\section{SECOND PHASE}

In the second phase the animals underwent nutritional adaptation of seven days with Standard commercial food and proceeded to change the ration to the Super Premium before supplementation with probiotics. Similarly to Phase 1 the day before the exchange the animals were fasted for 24 hours. The other procedures were similar to those performed in Phase 1.

\section{MICROBIOLOGICAL ANALYSIS}

Analyzed samples of water supplied to the animals and diets the quantification of fecal coliform. The feces animal were were collected up to 15 minutes after defecation placed in sterile plastic bags and taken immediately for analysis. All tests were performed according to Silva et al. (2001).

The presumptive test for coliforms was carried out using the Most Probable Number technique with test tubes containing Durham tubes and broth Lauryl Sulfate Tryptose (LST) twice concentrated 10 $\mathrm{mL}$ of water. After mixing tubes were incubated at $37 \mathrm{oC}$ for 24 hours in an environmental chamber.

Stool samples were analyzed in triplicate: 1) enumeration of Escherichia coli (agar eosin methylene blue - EMB) plates incubated at $37 \mathrm{oC}$ for 24 hours; 2) enumeration of lactic acid bacteria (agar Man, prayers and Shape - MRS) plates incubated at 30oC for 24-48 hours; 3) enumeration of Clostridium perfringens (SPS culture medium) plates incubated at $44 \mathrm{oC}$ under anaerobic conditions for 48 hours; and 4) enumeration of Bifidobacterium sp. (MRS medium) with plates incubated at $37 \mathrm{oC}$ under anaerobic for 72 hours (Camaschella et al., 1998).

\section{STATISTICAL ANALYSIS}

The experimental design used in the experiment was a completely randomized design with three treatments and six replications totaling 18 experimental units for all parameters.

Data were previous tested for normality of residual and homogeneity of variances ( $F$ test). When these assumptions were not met a logarithmic transformation was performed. The real average or transformed were evaluated by analysis of variance and separation of means by Tukey test and Student in PROC MEANS, SAS®. Use a nominal level of 5\% significance to detect differences between the logarithmic counts of colony forming units (UFC/g) of bacterial genera. Results of between 5 and 25\% were discussed because of its relevance against the variability of microbiological analysis. Such conduct has been applied previously by Swanson et al. (2002) studying the effects of pre and probiotics in healthy adults dogs. 


\section{RESULTS AND DISCUSSION}

Analyses of water and the diets fed animals during the experimental period showed no microbiological changes or was not checked the growth of total coliforms in the samples analysed.

The average number of E. coli, Clostridium perfringens, Bifidobacteruim sp. and Lactobacillus sp. stool for Phases 1 and 2 of the experiment characterized by the exchange of a Super Premium food for a Standard diet and Standard food for a Super Premium diet respectively are outlined in tables 1, 2, 3, 4, 5, 6,7 and 8.

Table 1 - Mean values of colony growth of E. coli (log MPN/g) observed in the fecal microflora characterized by the exchange of diet for puppies Beagle in Phase 1 of the experiment.

\begin{tabular}{lccccc}
\hline \multirow{2}{*}{ Dates } & \multicolumn{4}{c}{ Treatments } & \multirow{2}{*}{ P } \\
\cline { 2 - 4 } & Control & Probiotic 1 & Probiotic 2 & \\
\hline Day 1 & $5,49 \pm 0,79$ & $5,85 \pm 1,5$ & $6,24 \pm 0,52$ & \\
Day 3 & $7,22 \pm 1,62 \mathrm{a}$ & $5,14 \pm 0,32 \mathrm{~b}$ & $5,86 \pm 0,56 \mathrm{ab}$ & 0,89 & \\
Means & $6,35 \pm 1,47$ & $5,05 \pm, 098$ & $5,49 \pm 0,56$ & & \\
\hline
\end{tabular}

Means followed by different uppercase letters and lowercase letters separate column in the line differ by Student testa at nominal level of significance of 5\%. Dates: the fisrt (1) and last (3) date application of probiotics.

Table 2 - Mean values of colony growth of E. coli (log MPN/g) observed in the fecal microflora characterized by the exchange of diet for puppies Beagle in Phase 2 of the experiment.

\begin{tabular}{lllll}
\hline \multirow{2}{*}{ Dates } & \multicolumn{3}{c}{ Treatments } & \multirow{2}{*}{ P } \\
\cline { 2 - 4 } & \multicolumn{1}{c}{ Control } & \multicolumn{1}{c}{ Probiotic 1 } & \multicolumn{1}{c}{ Probiotic 2 } & \\
\hline Day 1 & $6,46 \pm 1,08$ & $4,76 \pm 1,29$ & $5,01 \pm 0,91$ & \\
Day 3 & $6,20 \pm 0,78$ & $4,81 \pm 0,50$ & $5,79 \pm 0,78$ & 0,56 \\
Means & $6,33 \pm 0,91 \mathrm{a}$ & $4,78 \pm 0,93 \mathrm{~b}$ & $5,40 \pm 0,90 \mathrm{ab}$ & \\
\hline
\end{tabular}

Means followed by different uppercase letters and lowercase letters separate column in the line differ by Student testa at nominal level of significance of 5\%. Dates: the fisrt (1) and last (3) date application of probiotics.

The average growth of E. coli in phases experimental characterized by exchanges of diets showed that the averages do not differ between treatments on day 1 . However on day 3 of phase 2 of the average result was no significant difference between the results obtained and observed a decreased in the average number of E. coli with the use of probiotics. These results contrast with those obtained by Swanson et al. (2002) who found no effects of Lactobacillus acidophilus on the population of E. coli in Beagles dogs.

These results can be explained in part by increased competition for membership of the intestinal mucosa by microorganisms. As expected supplementation with probiotics reduced the counts of E. coli in both phases of the experiment. This statement corroborates Tumola et al. (1999) had already shown that supplementation with probiotic bacteria reduce the adhesion of E. coli.

Note also that when considering the number of colonies of E. coli the values were lower with the use of probiotic 1 probably due to co aggregation between these bacterial genera which may have hindered the adhesion of E. coli. 
Regardless of the quality of dietary supplementation of both probiotics was effective. However best results were achieved in phase 2 when there was food exchange Standard for Super premium food. The food Super premium has better quality ingredients. In addition these foods contain ingredients with functional properties as prebiotics (frutoligosaccharide - FOS and mannanoligosaccharide - MOS) that may influence the establishment of the intestinal microbiota.

The FOS can be fermented by lactic acid bacteria but not by E. coli (Gibson et al. 2004). Already MOS can bind to type 1 fimbria bacteria such as E. coli preventing their adhesion to the intestinal mucosa (Middelbos et al. 2007).

Table 3 - Mean values of colony growth of Clostridium (log UFC/g) observed in the fecal microflora characterized by the exchange of diet for puppies Beagle in Phase 1 of the experiment.

\begin{tabular}{lllll}
\hline \multirow{2}{*}{ Dates } & \multicolumn{3}{c}{ Treatments } & \multirow{2}{*}{ P } \\
\cline { 2 - 4 } & \multicolumn{1}{c}{ Control } & Probiotic 1 & Probiotic 2 & \\
Day 1 & $3,79 \pm 1,65$ & $3,56 \pm 0,92$ & $5,21 \pm 1,03$ & \\
Day 3 & $5,15 \pm 0,83$ & $4,7 \pm 1,30$ & $4,25 \pm 0,50$ & 0,56 \\
Means & $4,47 \pm 0,91$ & $3,97 \pm 0,88$ & $4,73 \pm 1,19$ & \\
\hline
\end{tabular}

Nominal level of significance of 5\%. Dates: the fisrt (1) and last (3) date application of probiotics.

Table 4 - Mean values of colony growth of Clostridium (log UFC/g) observed in the fecal microflora characterized by the exchange of diet for puppies Beagle in Phase 2 of the experiment.

\begin{tabular}{lcccc}
\hline \multirow{2}{*}{ Dates } & \multicolumn{3}{c}{ Treatments } & \multirow{2}{*}{ P } \\
\cline { 2 - 4 } & Control & Probiotic 1 & Probiotic 2 & \\
\hline Day 1 & $4,68 \pm 1,11$ & $3,87 \pm 1,35$ & $3,71 \pm 1,19$ & \\
Day 3 & $4,49 \pm 0,65$ & $3,49 \pm 0,30$ & $4,24 \pm 1,22$ & 0,98 \\
Means & $4,59 \pm 0,87$ & $3,68 \pm 0,96$ & $3,97 \pm 1,18$ & \\
\hline
\end{tabular}

Nominal level of significance of 5\%. Dates: the fist (1) and last (3) date application of probiotics

Regarding the growth of Clostridium perfringens colonies was not possible to observe differences in phases 1 and 2 of the experiment.

These results corroborate the previously noted by Swanson et al. (2002) which did not identify the effect of supplementation with Lactobacillus acidoplilus to healthy adults dogs on the count of Clostridium perfringens.

Tabela 5 - Mean values of colony growth of Lactobacillus (log UFC/g)observed in the fecal microflora characterized by the exchange of diet for puppies Beagle in Phase 1 of the experiment.

\begin{tabular}{lcccc}
\hline \multirow{2}{*}{ Dates } & \multicolumn{3}{c}{ Treatments } & \multirow{2}{*}{ P } \\
\cline { 2 - 4 } & Control & Probiotic 1 & Probiotic 2 & \\
\hline Day 1 & $8,05 \pm 1,13$ & $8,02 \pm 0,90$ & $8,10 \pm 1,69$ & \\
Day 3 & $9,92 \pm 0,61$ & $9,29 \pm 0,20$ & $9,70 \pm 1,08$ & 0,79 \\
Means & $8,98 \pm 1,31$ & $8,66 \pm 1,00$ & $8,90 \pm 1,59$ & \\
\hline
\end{tabular}

Nominal level of significance of 5\%. Dates: the fist (1) and last (3) date application of probiotics. 
Tabela 6 - Mean values of colony growth of Lactobacillus (log UFC/g) observed in the fecal microflora characterized by the exchange of diet for puppies Beagle in Phase 2 of the experiment.

\begin{tabular}{lcccc}
\hline \multirow{2}{*}{ Dates } & \multicolumn{3}{c}{ Treatments } & \multirow{2}{*}{ P } \\
\cline { 2 - 4 } & Control & Probiotic 1 & Probiotic 2 & \\
\hline Day 1 & $9,88 \pm 0,75$ & $9,79 \pm 1,38$ & $9,80 \pm 0,70$ \\
Day 3 & $8,84 \pm 1,27$ & $8,39 \pm 1,09$ & $8,68 \pm 1,07$ & 0,60 \\
Means & $9,36 \pm 1,13$ & $9,09 \pm 1,40$ & $9,24 \pm 1,04$ & \\
\hline
\end{tabular}

Nominal level of significance of 5\%. Dates: the fist (1) and last (3) date application of probiotics.

There were no significant differences between Lactobacillus count in the days of the applications of probiotics in both phases of the experiment. As noted can't be influenced by the treatments on these variables. Significant effects were not found by Swanson et al. (2002) for probiotics supplements for adult dogs.

There is a significant numerical increase microbilogical point of view between 1 and 3 days in phases 1 and 2 of the experiment. In the first phase there is an increase in the count of $8 \log \mathrm{UFC} / \mathrm{g} f$ feces to 9 representing an increase of nearly onde hundred million to one billion colony and this occurred regardless of treatment applied but the form the change of diet. According Saad (2006) lower digestibility of foods provide a higher concentration of nutrients for bacterial fermentation enabling the growth of their populations.

Table 7 - Mean values of colony growth of Bifidobacterium (log UFC/g) observed in the fecal microflora characterized by the exchange of diet for puppies Beagle in Phase 1 of the experiment.

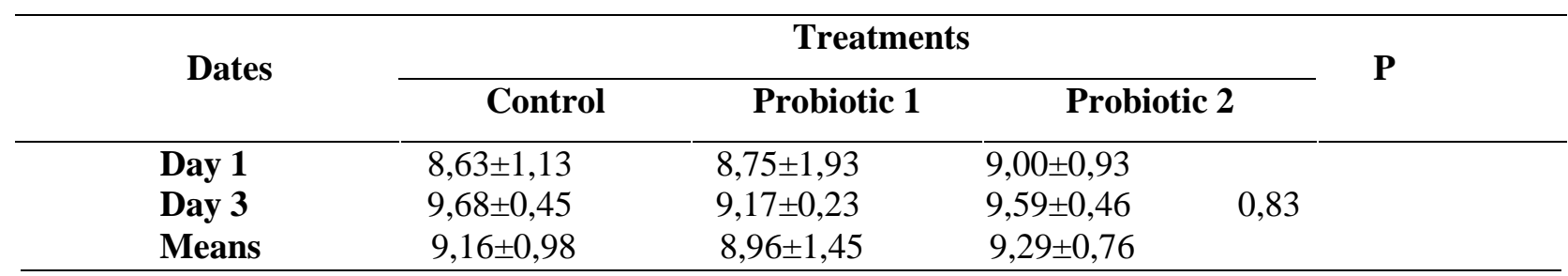

Nominal level of significance of 5\%. Dates: the fisrt (1) and last (3) date application of probiotics.

Table 8 - Mean values of colony growth of Bifidobacterium (log UFC/g) observed in the fecal microflora characterized by the exchange of diet for puppies Beagle in Phase 2 of the experiment.

\begin{tabular}{ccccc}
\hline \multirow{2}{*}{ Dates } & \multicolumn{3}{c}{ Treatments } & \multirow{2}{*}{ P } \\
\cline { 2 - 4 } & \multicolumn{1}{c}{ Control } & Probiotic 1 & \multicolumn{2}{c}{ Probiotic 2 } \\
Day 1 & $9,37 \pm 1,00$ & $8,84 \pm 0,42$ & $9,54 \pm 0,54$ & \\
Day 3 & $8,31 \pm 1,16$ & $8,02 \pm 0,78$ & $8,71 \pm 0,95$ & 0,71 \\
Means & $8,84 \pm 1,17$ & $8,43 \pm 0,74$ & $9,12 \pm 0,85$ & \\
\hline
\end{tabular}

Nominal level of significance of 5\%. Dates: the fistt (1) and last (3) date application of probiotics.

The same behavior observed for the Lactobacillus was repeated with colonies of Bifidobacterium. Thus rather than the separate administration of different probiotic diet quality seems to have influenced the growth of beneficial bacterial species. 
The means values of $\mathrm{pH}$ of the feces in Phases 1 and 2 of the experiment characterized by the exchange of diets are outlined in tables 9 and 10.

Table 9 - Mean values of fecal pH characterized by the exchange of diet for puppies Beagle in Phase 1 of the experiment.

\begin{tabular}{lcccc}
\hline \multirow{2}{*}{ Dates } & \multicolumn{3}{c}{ Treatments } & \multirow{2}{*}{ P } \\
\cline { 2 - 4 } & Control & Probiotic 1 & Probiotic 2 & \\
\hline Day 1 & $5,70 \pm 0,25$ & $5,67 \pm 0,24$ & $5,68 \pm 0,15$ & \\
Day 3 & $5,31 \pm 0,33$ & $5,50 \pm 0,12$ & $5,52 \pm 0,44$ & 0,99 \\
Means & $5,51 \pm 0,34$ & $5,58 \pm 0,20$ & $5,60 \pm 0,32$ & \\
\hline
\end{tabular}

Nominal level of significance of 5\%. Dates: the fisrt (1) and last (3) date application of probiotics.

Table 10 - Mean values of fecal $\mathrm{pH}$ characterized by the exchange of diet for puppies Beagle in Phase 2 of the experiment.

\begin{tabular}{|c|c|c|c|c|c|}
\hline \multirow{2}{*}{ Dates } & \multicolumn{4}{|c|}{ Treatments } & \multirow{2}{*}{$\mathbf{P}$} \\
\hline & Control & Probiotic 1 & Probiotic 2 & & \\
\hline Day 1 & $5,80 \pm 0,30$ & $5,77 \pm 0,32 \mathrm{Aa}$ & $5,80 \pm 0,30 \mathrm{Aa}$ & & \\
\hline Day 3 & $5,44 \pm 0,12 \mathrm{Bb}$ & $5,90 \pm 0,32 \mathrm{Aa}$ & $5,44 \pm 0,12 \mathrm{Bb}$ & 0,13 & \\
\hline Means & $5,62 \pm 0,29$ & $5,83 \pm 0,31$ & $5,62 \pm 0,29$ & & \\
\hline
\end{tabular}

Means followed by different uppercase letters and lowercase letters separate column in the line differ by Student testa at nominal level of significance of 5\%. Dates: the fisrt (1) and last (3) date application of probiotics.

The means of $\mathrm{pH}$ found $(5,51$ to 5,83) are slightly below measured by Swanson et al. (2002) ranging between 6,23 and 6,5 and 6,2 cited by Mentula (2005). There was no average decrease in fecal $\mathrm{pH}$ in phase 1 the date or the treatments. However the $\mathrm{pH}$ values in phase 2 have significant differences both in the light of days as the different types of probiotics applied. There was an increase of acidity in control and probiotic 2 with tima but not the same thing happened with a probiotic. This behavior caused a major effect of the probiotic 2 and control treatment compared to probiotic 1 in fecal $\mathrm{pH}$. It is suggested that the lower counts of lactic acid bacteria in a treatment could explain this behavior of $\mathrm{pH}$.

\section{CONCLUSION}

Its concluded that probiotics used showed no similarity in their functionality and the first probiotic containing Bifidobacterium, Lactobacillus and Enterococcus promoted greater benefits to the digestive tract of dogs due to decreased effective colonies of pathogenic microorganisms and can be considered that the use of functional foods can help and treatment of gastrointestinal disorders in puppies dogs. 


\section{REFERENCES}

CAMASCHELLA P., MIGNON O., PIROVANO F. et al. Method for differenziated enumeration of mixed cultures of thermophilic lactic acid bacteria and bifidobacteria by using only one culture medium. Le Lait, v.78, p.461-467, 1998.

COPPOLA, M.M.; TURNES, C.G. Probióticos e resposta imune. Ciência Rural, v.34, p.1297- 303, 2004.

FERNANDEZ, P.C.C.; LADEIRA, I.Q.; FERREIRA, C.L.L.F. et al. Viabilidade do uso de probióticos na alimenação de monogátricos. Caderno Técnico de Veterinária e Zootecnia, n.31, p.53-71, 2000.

GIBSON, G.R; PROBERT, H.M; VAN LOO, J; et al. Dietary modulation of the human colonic microbiota: updating the concept of prebiotics. Nutrition Research Reviews. v. 17, p. 259-275, 2004.

MENTULA, S. Analysis of canine small intestinal and fecal microbiota. National Public Health Institute, v.8, p.1-86, 2005.

MIDDELBOS, I.S; GODOY, M.R; FASTINGER, N.D; et al. A dose-response evaluation of spray-dried yeast cell wall supplementation of diets fed to adult dogs: Effects on nutrient digestibility, immune indices, and fecal microbial populations. Journal of Animal Science, v. 85, p. 3022-3032, 2007.

SAAD, S.M.I; Probióticos e prebióticos: o estado da arte. Revista Brasileira de Ciências Farmacêuticas, v.42, p. 1-16, 2006.

SILVA, N.; JUNQUEIRA, V. C. A.; SILVEIRA, N. F. A. Manual de métodos de análise microbiológica de alimentos. 2 ed. São Paulo: Varela, p. 295, 2001.

SWANSON, K.S., GRIESHOP, C.M., FLICKINGER, E.A. et al. Fructooligosaccharides and Lactobacillus acidophilus modify gut microbial populations, total tract nutrients digestibilities and fecal protein catabolite concentrations in healthy adult dogs. The Journal of Nutrition, v.132, p.3721-3731, 2002.

TUOMOLA, E. M; OWEHAND, A.C; SALMINEN, S. J. The effect of probiotic bacteria on the adhesion of pathogens to human intestinal mucus. FEMS Immunology and Medical Microbiology, v. 26, p. 137$142,1999$. 